\title{
PENGARUH PROFITABILITAS, DEWAN KOMISARIS, KOMISARIS INDEPENDEN DAN RISIKO IDIOSINKRATIS TERHADAP DIVIDEND PAYOUT RATIO
}

\author{
Rino Tam Cahyadi, Lilik Purwanti \& Endang Mardiati \\ Universitas Brawijaya, Indonesia \\ Email: rhinotamcahyadi@gmail.com
}

\begin{abstract}
Abstrak: Pengaruh Profitabilitas, Dewan Komisaris, Komisaris Independen dan Risiko Idiosinkratis Terhadap Dividend Payout Ratio. Penelitian ini bertujuan untuk menguji pengaruh langsung profitabilitas, dewan komisaris, komisaris independen, dan risiko idiosinkratis terhadap Dividend Payout Ratio (DPR). Teknik pemilihan sampel menggunakan purposive sampling dan analisis data menggunakan regresi data panel dengan model common effect. Hasil penelitian menunjukkan bahwa profitabilitas berpengaruh positif terhadap DPR, komisaris independen berpengaruh negatif terhadap DPR, sementara dewan komisaris dan risiko idiosinkratis tidak memiliki pengaruh terhadap DPR.
\end{abstract}

Kata Kunci: profitabilitas, Dewan Komisaris, Komisaris Independen, risiko idiosinkratis, Dividend Payout Ratio

\begin{abstract}
The Influence of Profitability, Board of Commissioners, Independent Commissioners, and Idiosyncratic Risk on Dividend Payout Ratio. This study aimed to empirically assess the influence of company's profitability, commissioners, independent commissioners, and idiosyncratic risk on Dividend Payout Ratio (DPR). Samples were selected by using purposive sampling method and this research utilize panel data regression with common effect model to analyze the data. This study found that, profitability had a significantly positive influence on DPR, independent commissioners had a significantly negative influence on DPR; and board of commissioners and idiosyncratic risk had no influence on DPR.
\end{abstract}

Keywords: profitability, board of commissioners, independent commissioners, idiosyncratic risks, dividend payout ratio

\section{PENDAHULUAN}

Bursa Efek Indonesia memiliki beberapa indeks harga saham salah satunya adalah indeks LQ45. Indeks LQ45 adalah kumpulan dari 45 emiten terbesar yang diukur melalui pertimbangan ukuran likuiditas dan pangsa pasar (Harahap, 2015:312). Perusahaan yang memiliki likuiditas tinggi dan masuk dalam indeks LQ45 seharusnya membagikan dividen secara rutin. Namun secara fakta, tidak semua perusahaan dalam kategori LQ45 membagikan return dalam bentuk dividen secara rutin. Peneliti menemukan ada beberapa emiten LQ45 yang tidak membagikan dividennya secara rutin yaitu emiten AALI tidak membagikan dividen pada tahun 2015, emiten ADHI tidak membagikan dividen pada tahun 2016, emiten ANTM tidak membagikan dividen pada tahun 2014 sampai dengan 2016 dan lain-lain.

Perusahaan LQ45 memiliki kondisi likuiditas terbaik dan memiliki pangsa pasar terbesar di antara semua emiten yang terdaftar di Bursa Efek Indonesia namun ada 
beberapa emiten yang tidak membagikan dividen. Fenomena ini mengartikan bahwa penentuan pembagian dividen tidak terpaku pada seberapa besar pangsa pasar, seberapa tinggi likuiditas perusahaan dan seberapa bagus laporan keuangan yang diungkapkan. Hal ini menarik peneliti untuk menelaah lebih dalam faktor-faktor apa saja yang mempengaruhi perusahaan dalam membagikan dividennya.

Investor dapat melihat kemampuan perusahaan dalam membagikan dividen dengan melihat nilai dari dividend payout ratio yang diungkapkan dalam laporan keuangan. Dividend Payout Ratio (DPR) adalah alat ukur yang digunakan oleh investor untuk melihat seberapa besar jumlah pembayaran dividen yang dilakukan oleh perusahaan. Nilai DPR yang semakin besar mengartikan bahwa perusahaan tersebut mampu membayar dividen dalam jumlah yang besar (Halviani, 2014). Nilai DPR menggambarkan seberapa besar return yang akan diterima investor ketika investor melakukan investasi saham. Meskipun demikian, pembagian return dalam bentuk dividen membutuhkan pertimbangan khusus.

Banyak penelitian mengenai faktorfaktor yang mempengaruhi DPR. Secara umum, besar kecilnya nilai dari DPR ini dipengaruhi oleh 2 kondisi yaitu kondisi keuangan perusahaannya dan kondisi pengawasan operasionalnya. Kondisi keuangan terkait dengan ketersediaan pendanaan internal sedangkan kondisi pengawasan operasional terkait dengan peranan dewan komisaris. Pecking Order Theory menyatakan bahwa perusahaan akan membiayai kebutuhannya dari pendanaan internal terlebih dahulu apabila pendanaan internal tidak mencukupi maka perusahaan akan membiayai pendanaan eksternal (AlNajjar dan Hussainey, 2009). Dividen merupakan salah satu arus kas keluar sehingga perusahaan membutuhkan pertimbangan khusus sebelum melakukan pembayaran dividen. Investor dapat menilai kondisi pendanaan internalnya baik atau tidak dengan melihat rasio keuangannya. Rasio yang dapat dijadikan pertimbangan adalah rasio profitabilitas ( Amidu, 2006). Rasio profitabilitas memiliki peranan untuk mengukur kinerja perusahaan dalam menghasilkan laba. Ketika investor mendapati ada masalah dalam kinerja keuangan maka investor bisa menduga ada potensi penundaan ataupun penurunan pembayaran dividen di periode bersangkutan maupun di masa yang akan datang. Sesuai dengan Pecking Order Theory, perusahaan akan membagikan dividen apabila kondisi pendanaan internalnya baik.

Faktor lain yang membentuk nilai DPR adalah kondisi pengawasan operasional. Teori Agensi menjelaskan bahwa ketika manajer selaku pihak internal memiliki informasi yang lebih banyak dari pada pihak eksternal maka hal itu akan menimbulkan asimetri informasi. Manajer lebih menguasai informasi karena manajer berhadapan langsung dengan kegiatan operasional perusahaan (Scott, 2015: 358). Selain itu, manajer memiliki sifat shirking yaitu lebih mengutamakan kepentingan pribadi dibandingkan kepentingan investor. Semakin banyak informasi yang tidak terpublikasikan dapat menyebabkan investor keliru dalam melakukan investasi dengan harapan memperoleh return dalam bentuk dividen. 
Battyacharya (2016) dan Firth (2016) menyatakan bahwa ketika dividen dibagikan maka hal tersebut merupakan upaya dari perusahaan untuk mengurangi konflik keagenan. Arus kas yang berlebih dalam perusahaan dibagikan dalam bentuk dividen agar dapat mengurangi kas yang digunakan oleh manajer (agen).

Pengawasan operasional dapat dilihat dari kualitas penerapan Good Corporate Governance (KNKG, 2006). GCG ini memiliki peranan penting dalam menjaga kredibilitas perusahaan salah satunya dengan melihat dari jumlah Dewan Komisaris dan Komisaris Independen yang ada dalam perusahaan. Jiraporn, dkk (2008) menyatakan bahwa Dewan Komisaris memiliki peranan sebagai perwakilan kepentingan pemegang saham di dalam perusahaan. Dewan Komisaris bertugas untuk mengawasi kinerja dari Dewan Direksi. Penelitian empiris mengenai pengaruh Dewan Komisaris terhadap DPR telah dilakukan. Chen, dkk (2011), Gill \& Abradovich (2012), Nuhu (2014) dan Jiraporn dkk (2008) menemukan bahwa Dewan Komisaris berpengaruh positif terdahap nilai DPR. Dewan Komisaris akan mendorong Dewan Direksi untuk bekerja dengan penuh rasa tanggung jawab kepada pemgang saham. Selain Dewan Komisaris, adanya Komisaris Independen juga menunjang fungsi pengawasan perusahaan. Komisaris Independen adalah Dewan Komisaris yang berasal dari luar perusahaan dan tidak memiliki hubungan khusus dengan perusahaan di mana dia diangkat menjadi Dewan Komisaris. Belden dkk (2005) dan Shabibi (2007) menyatakan bahwa adanya Dewan Komisaris Independen dapat mengurangi biaya agensi yang terjadi dan meyakinkan bahwa fungsi pengawasan telah berjalan dengan baik. Meskipun demikan, hasil yang berbeda ditemukan oleh Nuhu (2014), Nuhu (2014) menemukan bahwa hubungan Dewan Komisaris Independen terhadap DPR memiliki hubungan yang negatif karena sebagian besar jajaran dewan komisaris dan dewan direksi memiliki kepemilikan saham di dalam perusahaan. Shahid, dkk (2016) menemukan bahwa tidak ada pengaruh antara Dewan Komisaris Independen terhadap DPR.

Peneliti menggabungkan penelitian Halviani (2014) dan Bhattyacharya (2016). Halviani (2014) meneliti pengaruh ROA terhadap DPR dengan GCG sebagai moderasi. Halviani menggunakan populasi perusahaan real estate di Bursa Efek Indonesia. Hasil penelitian menunjukan bahwa ROA berpengaruh positif terhadap DPR dengan moderasi GCG. Bhattyacharya (2016) meneliti GCG terhadap DPR dengan risiko idiosinkratis sebagai moderasi. Bhattyacharya (2016) menggunakan populasi perusahaan di NYSE. Hasil penelitian menunjukkan bahwa GCG memiliki pengaruh positif terhadap DPR secara langsung. Hubungan keduanya diperlemah dengan adanya risiko idiosinkratis. Kedua penelitian tersebut perlu diteliti kembali karena peneliti ingin mengetahui apakah penerapan pecking order theory dan teori agensi dapat diterapkan secara bersamaan dalam keputusan pembagian dividen oleh perusahaan. Kebaruan penelitian ini adalah dengan menambahkan risiko idiosinkratis sebagai variabel independen.

Kontribusi penelitian ini ada dua yaitu kontribusi teoretis dan kontribusi praktis. 
Kontribusi teoretis penelitian ini adalah hasil penelitian mengenai pengaruh rasio profitabilitas terhadap DPR dapat memberikan bukti empiris tentang penerapan pecking order theory. Selain itu, hasil penelitian mengenai pengaruh Komisaris Independen terhadap DPR dapat memberikan bukti empiris tentang penerapan teori agensi. Hasil penelitian ini juga dapat dijadikan referensi untuk penelitian selanjutnya terkait dividend payout ratio. Kontribusi praktis penelitian ini adalah hasil penelitian mengenai pengaruh faktor profitabilitas dan Komisaris Independen terhadap DPR dapat dijadikan referensi perusahaan untuk menentukan kebijakan pembayaran dividen. Bagi investor, Hasil penelitian mengenai pengaruh profitabilitas dan Komisaris Independen terhadap DPR dapat dijadikan bahan pertimbangan untuk mengambil keputusan investasi saham di pasar modal dengan harapan untuk memperoleh return dalam bentuk dividen.

Peneliti mengacu pada teori pecking order dan teori agensi untuk menjawab permasalahan penelitian. Permasalahan penelitian pada penelitian ini ada 4 macam. Pertama, apakah rasio profitabilitas berpengaruh positif terhadap DPR. Kedua, apakah Dewan Komisaris berpengaruh positif terhadap DPR. Ketiga, apakah Dewan Komisaris Independen berpengaruh negatif terhadap DPR. Keempat, apakah risiko idiosinkratis berpengaruh negatif terhadap DPR.

Menurut pecking order theory, segala pembiayaan yang dilakukan perusahaan dibiayai dari pendanaan internal terlebih dahulu. Laba merupakan bentuk return atau ukuran kinerja perusahaan selama satu periode. Laba merupakan arus kas positif yang dihasilkan dari segala aktivitas yang ada di dalam perusahaan. Jika perusahaan menghasilkan laba yang semakin besar maka secara langsung pendanaan internal yang dimiliki perusahaan akan semakin besar pula (Mamduh, 2004). Pendanaan internal yang besar memiliki dampak positif bagi perusahaan yaitu perusahaan akan mampu membiayai segala pengeluaran yang diperlukan tanpa meminta bantuan sumber pendanaan eksternal (utang atau penerbitan saham). Laba juga berdampak terhadap kebijakan perusahaan dalam membagikan dividen. Pembayaran dividen secara umum diambil dari alokasi laba yang diperoleh dalam satu periode (Al-Kuwari,2009 dan Halviani, 2014). Jumlah laba yang semakin besar akan cenderung menghasilkan dividen yang semakin besar. Sesuai dengan agrumentasi di atas, jika perusahaan memiliki kecukupan pendanaan internal dalam bentuk laba maka pembiayaan dalam bentuk dividen kepada pemegang saham dapat meningkat.

Fahmi (2014:81) menyatakan rasio profitabilitas adalah alat ukur kinerja keuangan yang mengukur tingkat laba (return). Rasio profitabilitas adalah rasio yang mengukur seberapa besar tingkat laba yang diperoleh pada suatu periode. Ketika rasio profitabilitas ini tinggi mengartikan bahwa perusahaan mampu menghasilkan laba yang besar (Halviani, 2014). Perusahaan yang dapat menghasilkan laba besar maka dapat menghasilkan pendanaan internal yang besar pula. Cadangan kas yang tinggi ini akan meningkatkan peluang memberikan return dalam bentuk dividen sehingga 
berdampak positif terhadap dividend payout ratio (Amidu, 2006). Penelitian mengenai rasio profitabilitas telah dilakukan oleh Halviani (2014) dan Amidu (2006). Hasil penelitian menunjukkan bahwa return on asset berpengaruh positif terhadap DPR. Berdasarkan argumentasi pecking order theory dan penelitian terdahulu dapat dirumuskan hipotesis pertama adalah rasio profitabilitas berpengaruh positif terhadap

\section{Dividend Payout Ratio}

Teori agensi menyatakan bahwa ketika principal mempercayakan sumberdayanya kepada agen untuk dikelola dengan atas nama principal maka hal ini akan menimbulkan asimetri informasi. Asimetri informasi ini terjadi ketika pihak agen mengetahui informasi perusahaan lebih banyak dibandingkan dengan pihak principal (Scott, 2014:24). Asimetri informasi yang sangat besar akan memungkinkan manajer untuk bertindak shirking tanpa diketahui oleh principal. Dampaknya, pihak principal akan dirugikan akibat adanya asimetri informasi ini.

Sesuai dengan teori agensi tersebut, pihak yang hanya membeli saham (Investor) tidak mengetahui informasi perusahaan secara lengkap karena investor tidak dekat dengan kegiatan operasional perusahaan. Oleh sebab itu, pemegang saham memerlukan perwakilan yang mampu mewakili kepentingan investor dalam perusahaan. Nuhu (2014) dan Bhattacharya (2016) menyatakan bahwa peran Dewan Komisaris mampu menjembatani kepentingan investor dengan manajer sehingga asimetri informasi dapat dikurangi. KNKG (2006) menyatakan bahwa dengan menerapkan Good Corporate Government maka principal dapat meningkatkan kualitas pengawasan terhadap tindakan yang dilakukan oleh agen untuk mengurangi tingkat asimetri informasi. Pengawasan yang dilakukan Dewan Komisaris akan membantu pemegang saham dalam menjaga independensi Dewan Direksi .

Nuhu (2014) dan Battacharya (2006) menyatakan bahwa kehadiran dari Dewan Komisaris akan menunjang keefektifan pengawasan principal. Dewan Komisaris memiliki tugas untuk mengawasi kinerja dan sebagai penasihat Direksi. Dewan Komisaris ditunjuk langsung oleh pemegang saham berdasarkan persetujuan RUPS. Peran Dewan Komisaris sebagai perwakilan kepentingan pemegang saham dalam perusahaan. Belden (2005) menyatakan semakin banyak jumlah Dewan Komisaris maka ruang lingkup pengawasan semakin luas. Dewan Komisaris akan mengawasi Direksi agar tidak mengabaikan kepentingan pemegang saham.

Pembentukan Dewan Komisaris dapat berhubungan langsung ke dividend payout ratio. Dalam penelitian Battacharya (2016) yang meneliti pengaruh GCG terhadap DPR dengan idiosyncratic risk sebagai moderasi ditemukan bahwa DPR akan meningkat jika perusahaan memiliki GCG yang baik dengan idiosyncratic risk yang rendah. Risiko tersebut merupakan risiko individu perusahaan yang tidak bisa diprediksi kedatangannya. Jika Dewan Komisaris menjalankan perannya dengan baik maka manajer berusaha mensejahterakan kepentingan principal sehingga berakibat pada pembayaran dividen yang meningkat (Chen dkk, 2011; Gill \& Abradovich, 2012; Nuhu, 2014 dan Jiraporn dkk, 2008). 
Pembayaran dividen yang besar akan membuat kelebihan kas yang dikelola agen dapat dikurangi sehingga meminimalkan penyalahgunaan kas yang dilakukan agen (Firth, 2016). Pembayaran dividen ini diimbangi dengan kecukupan pendanaan internal yang ada. Berdasarkan agrumentasi teori agensi dan penelitian terdahulu dapat dirumuskan hipotesis kedua adalah Dewan Komisaris berpengaruh positif terhadap Dividend Payout Ratio.

Teori Agensi menjelaskan ketika adanya asimetri informasi maka menimbulkan biaya agensi. Biaya tersebut dapat diminimalisir dengan membentuk suatu organ perusahaan yang bersifat independen. Selain kehadiharan dari Dewan Komisaris, KKNG (2006:13) menyatakan di dalam jajaran Dewan Komisaris dibentuk sebuah jajaran independen yang disebut sebagai Komisaris Independen. Komisaris Independen beranggotakan orang dari luar perusahaan yang tidak memiliki hubungan istimewa dengan perusahaan tempat dia diangkat menjadi Komisaris Indenpeden. Komisaris Independen merupakan perwakilan pemegang saham minoritas. Komisaris Independen akan berupaya menjamin terpenuhinya hak dari pemegang saham minoritas.

Penelitian sebelumnya mengenai hubungan Dewan Komisaris Independen dengan DPR telah dilakukan oleh Nuhu (2014). Nuhu (2014) menyatakan bahwa Komisaris Independen akan lebih mengutamakan capital gain dibandingkan pembagian dividen. Hal ini disebabkan karena semua jajaran Dewan Komisaris Independen lebih menyarankan kepada perusahaan untuk menanamkan laba di dalam perusahaan sebagai peluang investasi perusahaan karena hal itu dianggap lebih menguntungkan pemegang saham minoritas di masa yang akan datang. Belden (2005) menyatakan bahwa peran Dewan Komisaris Independen dapat mengurangi biaya agensi dalam perusahaan. Meskipun demikian, Bhagat dan Black (2012) menemukan bahwa semakin besar jumlah Dewan Komisaris Independen maka akan menimbulkan masalah agensi. Transfer keahlian kepada jajaran Dewan Direksi sebagai bentuk kerjasama tim tidak berjalan efektif dan tidak dapat melindungi kepentingan pemegang saham. Al-Najjar dan Hussainey (2009) mendukung penelitian Bhagat (2012) dan Nuhu (2014) bahwa hubungan Dewan Komisaris Independen terhadap DPR negatif. Berdasarkan agrumentasi teori agensi dan penelitian terdahulu dapat dirumuskan hipotesis ketiga adalah Dewan Komisaris Independen berpengaruh negatif terhadap Dividend Payout Ratio

Pecking order theory menyatakan bahwa sumber pendanaan internal akan membantu perusahaan dalam mendanai semua pengeluaran perusahaan, namun apabila pendanaan internal tidak mencukupi maka dibutuhkan pendanaan eksternal (utang) atau menerbitkan saham. Perusahaan secara tidak langsung harus mengutamakan pendanaan internal terlebih dahulu untuk membiayai segala pengeluaran. Jika perusahaan terlalu sering menggunakan pendanaan eksternal untuk menutup pengeluaran internal maka hal tersebut merupakan gejala perusahaan mengalami kesulitan keuangan. Menjaga kestabilan pendanaan internal merupakan hal yang penting bagi perusahaan. 
Levy (1978) menyatakan bahwa risiko idiosinkratis merupakan risiko unik yang ada dalam setiap perusahaan yang dapat dicontohkan dalam bentuk risiko likuiditas, risiko kredit, risiko kebangkrutan dan risiko hukum. Risiko ini timbul di luar rencana perusahaan dan setiap perusahaan memiliki risiko idiosinkratis yang berbeda. Dampak dari risiko ini adalah dapat memunculkan adanya asimetri informasi terkait actual return dengan expected return dari saham perusahaan (Murhadi, 2013). Stultz (1990) menyatakan risiko idiosinkratis ini akan berdampak pada nilai investasi. Ketika perusahaan memiliki risiko idiosinkratis rendah maka akan terjadi overinvestment (Jensen, 1986). Nilai investasi overinvestment akan merugikan perusahaan apabila perusahaan memutuskan untuk mencari pendanaan eksternal.

Bhattyacharya (2016) menyatakan bahwa dividend dikeluarkan pada saat perusahaan mengalami overinvestment. Kondisi overinvestment yang terbentuk dari risiko idiosinkratis mengartikan bahwa perusahaan tidak sedang membutuhkan pendanaan eksternal. Oleh sebab itu, risiko idiosinkratis yang rendah mempunyai makna bahwa perusahaan memiliki kecukupan dana internal sehingga perusahaan mampu membayar dividen kepada pemegang saham. Sebaliknya, jika risiko idiosinkratis semakin tinggi maka nilai investasi akan cenderung underinvestment. $\mathrm{Hal}$ itu disebabkan dari risiko idiosinkratis yang tinggi akan mendorong manajemen untuk mengurangi return dalam bentuk dividen. Risiko yang terlalu tinggi mengartikan bahwa perusahaan sedang membutuhkan pendanaan eksternal sehingga pengeluaran dalam bentuk dividen tidak diutamakan (Bhattyacharya, 2016). Berdasarkan agrumentasi pecking order theory dapat dirumuskan hipotesis keempat adalah risiko idiosinkratis berpengaruh negatif terhadap Dividend Payout Ratio.

\section{METODE}

Penelitian ini masuk dalam paradigma positivis dengan pendekatan kuantitatif.

Tabel 1. Sampel Penelitian

\begin{tabular}{cll}
\hline NO & KODE EMITEN & NAMA EMITEN \\
\hline 1 & ADRO & PT. Adaro Energy Tbk. \\
2 & AKRA & AKR Corporindo Tbk. \\
3 & ASII & Astra International Tbk. \\
4 & BBCA & Bank Central Asia Tbk. \\
5 & BBNI & Bank Negara Indonesia (Persero) Tbk. \\
6 & BBRI & Bank Rakyat Indonesia (Persero) Tbk. \\
7 & BMRI & Bank Mandiri (Persero) Tbk. \\
8 & GGRM & Gudang Garam Tbk. \\
9 & INDF & Indofood Sukses Makmur Tbk. \\
10 & INTP & Indocement Tunggal Prakasa Tbk. \\
11 & KLBF & Kalbe Farma Tbk. \\
12 & LSIP & PP London Sumatera Tbk. \\
13 & PTBA & Tambang Batubara Bukit Asam (Persero) Tbk. \\
14 & UNTR & United Tractors Tbk. \\
15 & UNVR & Unilever Indonesia Tbk. \\
\hline
\end{tabular}


Dalam Efferin dkk (2012:63), jenis penelitian ini disebut hypothesis testing. Hypothesis testing adalah penelitian yang menjelaskan pengujian hipotesis yang bersifat kausal antar variabel penelitiannya. Variabel dependen yang akan diteliti adalah dividend payout ratio. Variabel independen yang akan diteliti meliputi rasio profitabilitas, Dewan Komisaris, Komisaris Independen dan risiko idiosinkratis. Penelitian ini menggunakan populasi perusahaan yang masuk ke dalam indeks LQ45. Alasan dipilihnya LQ45 karena indeks tersebut merupakan kumpulan emiten yang memiliki likuiditas dan pangsa pasar terbesar di $\mathrm{BEI}$ sehingga dapat mewakili populasi seluruh emiten di BEI. Rentan waktu yang dipilih adalah tahun 2012-2016 untuk memperoleh hasil penelitian yang terbaru terkait faktor yang mempengaruhi dividend payout ratio di Indonesia. Teknik pemilihan sampel menggunakan teknik purposive sampling. Pengambilan sample dengan metode purposive sampling ini perlu dibuat kriteria. Kriteria sampel yang ditentukan adalah perusahaan yang masuk kategori indeks LQ45 tahun 2012-2016, perusahaan yang konsisten masuk indeks LQ45 tahun 20122016, perusahaan membagikan dividen secara rutin selama tahun 2012 sampai dengan tahun 2016 karena fokus penelitian ini untuk menguji faktor-faktor yang mempengaruhi perusahaan dalam membagikan dividen.

Teknik pengumpulan data yang digunakan adalah metode dokumentasi. Teknik dokumentasi adalah pengumpulan data tentang hal-hal atau variabel yang berupa catatan, majalah, prasasti, laporan, transkrip, buku maupun surat kabar kemudian didokumentasikan ke bentuk sederhana. Jenis data pada penelitian ini adalah data kuantitatif. Ditinjau dari sumbernya, data yang dipakai adalah data sekunder dari laporan keuangan yang disajikan pada situs www.idx.co.id. Laporan keuangan yang digunakan adalah laporan keuangan tahunan perusahaan index LQ45 periode 2012-2016.

DPR adalah alat ukur untuk mengukur kemampuan perusahaan dalam membagikan dividen. DPR dalam penelitian ini diukur dengan membandingkan dividend per share dengan earning per share sesuai dengan penelitian Amidu dan Abor (2006) dan Efendi (2007) karena data yang disajikan juga menggunakan rumus yang sama.

$\begin{aligned} \mathrm{Y}= & \frac{\text { Dividen } \text { per } \text { share }}{\text { Earning } \text { per } \text { share }} \\ & \text { Rasio profitabilitas adalah rasio }\end{aligned}$ keuangan yang digunakan untuk mengukur kemampuan perusahaan dalam memperoleh laba. Rasio profitabilitas pada penelitian ini diukur melalui Return on Asset. Dalam Halviani (2014) dan Nuhu (2014), ROA diukur dengan membandingkan laba bersih setelah pajak dengan total asset. Berikut adalah rumus dari ROA

$\mathrm{ROA}=\frac{\text { Total Laba bersih setelah pajak }}{\text { Total Aset }}$

Dewan Komisaris adalah salah satu organ perusahaan yang ditunjuk langsung dalam RUPS yang bertujuan untuk mengawasi kegiatan dari jajaran direksi. Nuhu (2014) dan Shahid (2016) mengukur Dewan Komisaris melalui jumlah anggota Dewan Komisaris.

Boediono (2005) dan Nuhu (2014) mengukur dewan komisaris independen dengan cara memproporsikan jumlah 
anggota dewan komisaris independen dengan jumlah anggota dewan komisaris.

$\mathrm{KI}=\frac{\text { Jumlah Komisaris Independen }}{\text { Total Anggota Komisaris }} \times 100 \%$

Risiko idiosinkratis adalah risiko unik yang ada dalam setiap perusahaan. Risiko ini dinilai dari nilai residual error dari model regresi CAPM (Muhardi, 2013). Adapun rumus untuk mencari risiko idiosinkratis adalah sebagai berikut :

$\mathrm{R}_{\mathrm{i}, \mathrm{t}}=\mathrm{R}_{\mathrm{f}, \mathrm{t}}+\beta\left(\mathrm{R}_{\mathrm{m}, \mathrm{t}}-\mathrm{R}_{\mathrm{f}, \mathrm{t}}\right)+\alpha_{\mathrm{i}, \mathrm{t}}$

$R_{i, t}$ adalah return saham individual, $R_{m, t}$ adalah return pasar, $\mathrm{R}_{\mathrm{f}, \mathrm{t}}$ adalah risiko bebas, $\alpha_{i, t}$ adalah nilai residual regresi. Nilai residual regresi adalah risiko idiosinkratis yang diperoleh dari regresi excess return $\left(R_{i, t}-R_{f, t}\right)$ dengan excess market return $\left(R_{m, t}-R_{f, t}\right)$. $R_{i, t}$ diperoleh dari perbandingan antara return harga saham/bulan ditambah pembagian dividen lalu dibagi dengan harga saham bulan lalu.

Data penelitian ini merupakan data panel sehingga perlu digunakan uji regresi khusus untuk data panel (Yamin, 2011 : 199-200). Uji autokorelasi dinyatakan melalui nilai Durbin Watson dengan dibandingkan pada titik kritisnya. Penelitian ini menggunakan $n$ sebesar 75 dan $k$ sebesar 4 sehingga diperoleh dL sebesar 1,5151 dan dU sebesar 1,7390. Nilai 4-dU sebesar 2,261 sedangkan nilai 4-dL sebesar 2,4849. Nilai d pada penelitian ini adalah 2,074595. Nilai tersebut berada di antara 1,7390 (dU) dengan 2,261 (4-dU). Hasil statistik menunjukkan bahwa tidak terdapat adanya masalah autokorelasi.

Uji Heterokedasitas dilakukan dengan cara meregres nilai absolut residual dengan variabel independen. Nilai probability value probability value $>0,05$ mengartikan bahwa penelitian ini terbebas dari masalah heterokedasitas (lihat Tabel 2). Begitu juga dengan multikolinearitas, oleh karena korelasi antar variabel bebas berkisar antara $-0,416$ s.d. $-0,006$, maka model terbebas dari multikolinearitas.

Tabel 2. Hasil Uji Heterokedasitas

\begin{tabular}{lcc}
\hline Variabel & t-Statistic & Prob \\
\hline ROA & -1.87847 & 0.0655 \\
DK & 0.79562 & 0.4296 \\
KI & 0.38590 & 0.7010 \\
ID & 0.22366 & 0.8238 \\
\hline
\end{tabular}

Model regresi data panel terbagi menjadi 3 macam yaitu common effect, fixed effect dan random effect. Untuk menentukan model mana yang paling cocok dilakukan langkah berikut. Pertama, dilakukan uji Chow untuk memiliki model yang paling baik antara common effect dan fixed effect. Nilai dari probability Chi-Square sebesar 0,1077. Hasilnya menunjukkan bahwa nilai tersebut lebih tinggi dari 0,05 sehingga model common effect yang terbaik diterima.

Langkah berikutnya dilakukan uji uji Hausment untuk memilih model yang paling baik antara model fixed effect dan model random effect. Hasilnya menunjukkan bahwa nilai probability cross section random sebesar 0,1687. Oleh karena nilai probabilitas cross-section random lebih tinggi dari 0,05 maka model random effect yang terbaik diterima. Langkah terakhir dilakukan uji LM untuk memilih model yang terbaik antara common effect dan random effect. Hasilnya menunjukkan bahwa nilai probability Breusch-Pagan sebesar 0,7237. Oleh karena nilai probability Breusch-Pagan lebih besar dari 0,05 maka model common effect yang terbaik diterima. 
Tabel 3. Hasil Pengujian Hipotesis

\begin{tabular}{cccc}
\hline Variable & t-Statistic & Prob & Keputusan \\
\hline ROA & 6.42193 & 0.0000 & Diterima \\
DK & -0.85122 & 0.3975 & Ditolak \\
KI & -2.42694 & 0.0178 & Diterima \\
ID & -1.44441 & 0.1531 & Ditolak \\
\hline
\end{tabular}

\section{HASIL DAN PEMBAHASAN}

Hipotesis satu menyatakan bahwa profitabilitas berpengaruh positif terhadap DPR. Hasil pengujian menunjukkan bahwa hipotesis satu diterima (lihat Tabel 3). Hasil penelitian konsisten dengan penelitian sebelumnya yaitu penelitian Halviani (2014) dan Amidu (2006) yang menemukan bahwa profitabilitas berpengaruh positif terhadap DPR. Hasil penelitian tidak mendukung penelitian Swastyastu (2014) yang menemukan bahwa profitabilitas tidak berpengaruh terhadap DPR.

Hasil penelitian mendukung pecking order theory yang menyatakan bahwa perusahaan akan membiayai segala pengeluarannya dengan mengutamakan pendanaan internal terlebih dahulu. Laba merupakan sumber pendanaan internal perusahaan yang diukur melalui tingkat profitabilitasnya. Jika nilai profitabilitas perusahaan semakin tinggi maka perusahaan akan memperoleh pendanaan internal yang semakin tinggi pula. Perusahaan yang memiliki pendanaan internal yang besar akan mampu membiayai pengeluarannya khususnya pengeluaran dalam bentuk pembagian dividen.

Amidu (2006), Al-Kuwari (2009) dan Halviani (2014) menyatakan bahwa profitabilitas yang tinggi akan meningkatkan pembayaran dividen. Kebijakan dividen pada umumnya ditentukan dari saldo laba yang diperoleh pada periode tertentu. Oleh sebab itu, jika perusahaan memperoleh profitabilitas tinggi pada suatu periode maka saldo laba yang diperoleh juga akan tinggi. Jumlah saldo laba yang tinggi akan berdampak terhadap kenaikan jumlah dividen yang dibagikan kepada pemegang saham.

Hipotesis dua menyatakan bahwa Dewan Komisaris berpengaruh positif terhadap Dividend Payout Ratio. Hasil pengujian hipotesis kedua menemukan bahwa Dewan Komisaris tidak berpengaruh terhadap dividend payout ratio. Dewan komisaris dalam penelitian ini diukur dengan jumlah anggota Dewan Komisaris. Hasil pengujian menunjukkan bahwa hipotesis kedua ditolak. Hasil penelitian tidak mendukung penelitian sebelumnya yaitu Chen dkk (2011), Gill \& Abradovich (2012), Nuhu (2014) dan Jiraporn, dkk (2008) yang menemukan bahwa Dewan Komisaris berpengaruh positif terhadap dividend payout ratio.Hasil penelitian konsisten dengan Triwulan dan Wahidahwati (2012) yang menyatakan bahwa Dewan Komisaris tidak berpengaruh terhadap kebijakan dividen.

Dewan Komisaris tidak berpengaruh terhadap dividend payout ratio. Triwulan dan Wahidahwati (2012) menyatakan bahwa peran utama dari Dewan Komisaris adalah menjamin pelaksanaan strategi perusahaan untuk memaksimumkan nilai perusahaan. Dewan Komisaris sebagai organ perusahaan 
hanya bertugas sebagai perwakilan pemegang saham untuk mengawasi dan memberi nasihat kepada direksi. Dewan Komisaris tidak diperkenankan ikut campur dalam pengambilan keputusan operasional. Oleh sebab itu, Dewan Komisaris tidak ikut campur dalam pengambilan keputusan terkait pembagian dividen kepada pemegang saham. Dewan Komisaris hanya sebatas memberikan saran dan masukan kepada Dewan Direksi terkait hal-hal yang patut dilakukan sesuai dengan strategi perusahaan dan prinsip good corporate governance. Peran Dewan Komisaris yang paling utama adalah mensejahterakan pemegang saham melalui peningkatan nilai perusahaan (harga saham) bukan dari pembagian dividen. Triwulan dan Wahidahwati (2012) menyatakan peningkatan nilai perusahaan jauh lebih penting bagi perusahaan karena nilai perusahaan merupakan faktor utama agar perusahaan dapat tetap bertahan dan mampu meminimalisir risiko kebangkrutan. Teori irrelevan dividen menyatakan bahwa pembagian dividen tidak mampu meningkatkan nilai perusahaan. Oleh sebab itu, Dewan Komisaris tidak berpengaruh terhadap dividend payout ratio.

Hipotesis ketiga menyatakan bahwa Komisaris Independen berpengaruh negatif terhadap dividend payout ratio. Hasil pengujian hipotesis menunjukkan bahwa hipotesis ketiga diterima. Hasil penelitian mendukung penelitian sebelumnya yaitu AlNajjar dan Hussainey (2009), Bhagat (2012) dan Nuhu (2014) yang menemukan bahwa Komisaris Independen berpengaruh negatif terhadap dividend payout ratio. Hasil penelitian tidak mendukung penelitian
Shababi dan Ramesh (2011) yang menemukan bahwa Komisaris Independen berpengaruh positif terhadap DPR. Peran Komisaris Independen adalah sebagai pengawas kinerja dari Dewan Direksi sehingga dapat meminimalkan biaya agensi antara pemegang saham minoritas dengan Dewan Direksi. Meskipun demikan, Bhagat dan Black (2012) menyatakan bahwa jumlah jajaran Dewan Komisaris Independen yang terlalu banyak justru menimbulkan masalah keagenan. Masalah keagenan yang muncul berupa adanya kerja sama tim yang tidak berjalan efektif sehingga tidak dapat melindungi kepentingan pemegang saham. Komposisi Komisaris Independen yang terlalu banyak akan menyebabkan koordinasi yang dilakukan berjalan kurang efektif.

Nuhu (2014) menemukan bahwa Komisaris Independen berpengaruh negatif terhadap dividend payout ratio. Komisaris Independen memiliki peranan untuk mengawasi Direksi agar jajaran Direksi berjalan sesuai visi misi perusahaan. Nuhu (2014) menyatakan bahwa jajaran Komisaris Independen lebih menyarankan untuk menginvestasikan saldo laba perusahaan di dalam perusahaan daripada dibagikan dalam bentuk dividen. Jajaran Komisaris Independen menilai bahwa penanaman saldo laba di dalam perusahaan akan meningkatkan nilai perusahaan di masa depan sehingga pemegang saham akan memperoleh keuntungan lebih tinggi di masa yang akan datang melalui kenaikan nilai perusahaan dibandingkan memperoleh dividen pada periode tersebut. Oleh sebab itu, adanya Komisaris Independen 
berpengaruh negatif terhadap dividend payout ratio.

Hipotesis keempat menyatakan bahwa risiko idiosinkratis berpengaruh negatif terhadap dividend payout ratio. Hasil pengujian hipotesis menemukan bahwa hipotesis keempat ditolak. Penelitian terdahulu mengenai hubungan langsung risiko idiosikratis terhadap dividend payout ratio masih belum ditemukan. Penelitian ini tidak berhasil membuktikan bahwa risiko idiosinkratis memiliki pengaruh langsung terhadap dividend payout ratio meskipun secara teoretis risiko tersebut memiliki pengaruh negatif terhadap dividen.

Referensi penelitian terdahulu secara umum menghubungkan risiko idiosinkratis terhadap nilai investasi. Levy (1978), Murhadi (2013) dam Stulz (1990) menghubungkan risiko idiosinkratis terhadap nilai investasi dan pengaruhnya terhadap return saham. Mereka menemukan bahwa risiko idiosinkratis yang tinggi akan berdampak pada nilai investasi undervalue. Nilai investasi undervalue akibat dari risiko idiosinkratis akan mendorong perusahaan untuk melakukan pendanaan eksternal melalui penerbitan saham baru. Oleh sebab itu, risiko idiosinkratis tidak berpengaruh terhadap dividend payout ratio.

\section{SIMPULAN}

Penelitian ini ditujukan untuk meneliti profitabilitas, dewan komisaris, komisaris independen dan risiko idiosinkratis terhadap DPR. Penelitian ini menggunakan sampel berupa data laporan keuangan dan historical data dari harga saham pada perusahaan yang masuk kategori indeks LQ45.
Secara keseluruhan penelitian ini menemukan bahwa nilai profitabilitas yang tinggi cenderung membuat perusahaan mampu membagikan dividen tinggi. Sementara itu, jumlah Komisaris Independen yang tinggi cenderung untuk membagikan dividen lebih sedikit. Informasi ini dapat digunakan sebagai referensi bagi penelitian berikutnya dan bagi investor sebagai bahan pertimbangan untuk mengambil keputusan investasi.

Penelitian ini memiliki tingkat $R$-Square sebesar $39 \%$. Hal tersebut menunjukkan bahwa masih ada $61 \%$ variabel lain yang mempengaruhi dividend payout ratio. Selain itu, penelitian ini gagal membuktikan bahwa risiko idiosinkratis memiliki pengaruh langsung terhadap DPR. Referensi-referensi penelitian terdahulu menyatakan bahwa risiko idiosinkratis berpengaruh langsung terhadap return saham. Oleh sebab itu, penelitian selanjutnya sebaiknya meneliti pengaruh tidak langsung risiko idiosinkratis terhadap DPR melalui return saham.

\section{DAFTAR PUSTAKA}

Al-Kuwari, D. (2009) "Determinants of the Dividend Policy in Emerging Stock Exchanges: The Case of GCC Countries". Global Economy \& Finance Journal, 2(2), 38-63.

Al-Najjar, B and Hussainey, K. (2009) "The Association between Dividend Payout and Outside Directorship". Journal of Applied Accounting Research., 10(1), 419.

Amidu, Mohammed dan Abor, Joshua. (2006) "Determinants of Dividend Payout Ratios in Ghana". The Journal of Risk Finance, 7(2), 136-145. 
Belden, S., Fister, T \& Knapp, B. (2005) "Dividends and Directors; Do Outsiders Reduce Agency Costs?". Business and Society Review, 110(2), 171-180.

Bhagat, S \& Black, B. (2002) "The NonCorelation Between Board Independence and Long-Term Firm Performance". Jurnal of Corporation Law, 27(2), 231-273.

Bhattacharya, Debarati et al. (2016) Does Better Corporate Governance Encourage Higher Payout?. Diakses dari http://www.fmaconferences.org/Boston /Does_Better_Corporate_Governance_E ncourage_Payout_Idiosyncratic_Risk,_A gency_Problem,_and_Dividend_Policy.p $\mathrm{df} \& \mathrm{rct}=\mathrm{j} \& \mathrm{sa}=U$ \&ved=2ahUKEwjqjqOFys 3aAhXEq48KHYjPCkMQFjACegQIBBAB\& $q=$ debarati+does+better+corporate+gov ernan\&usg=AOvVaw3k4Rd-

HOyHR1ve67Aq0osA9 pada tanggal 17 Juni 2017.

Boediono, Gideon SB. (2005) "Kualitas Laba: Studi Pengaruh Mekanisme Corporate Governance and Firm Perfomance : An Empirical Analysis". Financial Review. 33,1-16.

Chen, L., C. Lin., dan Yong-Cheol, K. (2011) "Financial Characteristic, Corporate Governance and the Propensity to Pay Cash Dividends of Chinese Listed Companies". International Business and Management, 3(1),176-188.

Efendi. (2007) "Analisis Faktor-Faktor Yang Mempengaruhi Dividend Payout Ratio Pada Industri Manufaktur Di Bursa Efek Jakarta (Periode 2002-2004)". Tesis. Universitas Diponegoro.

Efferin, Sujoko; Darmadji, Stevanus H \& Tan, Yuliawati. (2012) Metode Penelitian Akuntansi Pengungkapan Fenomena dendan Pendekatan Kuantitatif dan Kualitatif. Yogyakarta: Graha IImu.
Fahmi, Irham. (2014) Manajemen Keuangan Perusahaan Dan Pasar Modal. Jakarta : Mitra Wacana Media.

Firth, Michael., et, al. (2016) "Institutional Stock Ownership and Firm Cash Dividend Policies: Evidence From China". Journal of Banking \& Finance, 65, 91-107.

Gill, A.S., \& Obradovich, J. D. (2012) "Corporate Governance, institutional ownership and the decision to pay the amount of dividends : Evidence from USA". International Research Journal of Finance and Economics, 97, 60-71.

Halviani, Made Dwi dan Sisdyani, Eka Ardhani. (2014) "Pengaruh Moderasi Good Corporate Governance Pada Return On Asset dan Dividend Payout Ratio". E-Jurnal Akuntansi Universitas Udayana, 7(2), 332-344.

Harahap, Sofyan Syafri. (2015) Teori Akuntansi Edisi Revisi 2011. Jakarta: PT Raja Grafindo Persada.

Jiraporn, P., Kim, J and Kim, Y. (2008) Dividend Policy and Corporate Governance Quality. Working Paper. Pennsylvania University.

KNKG. (2006) Pedoman Umum Good Corporate Governance Indonesia.

Levy, H. (1978) "Equilibrium in an Imperfect Market: A Constraint on the Number of Securities in the Portfolio". American Economic Review, 68, 643-658.

Mamduh, Hanafih. (2004) Manajemen Keuangan. Yogyakarta:BPFE.

Murhadi, Werner R. (2013) "Pengaruh Idiosyncratic Risk Dan Likuiditas Saham Terhadap Return Saham". Jurnal Manajemen dan Kewirausahaan, 15(1), 33-40.

Nuhu, Eliasu. (2014) "Revisiting the Determinants of Dividend Payout Ratios in Ghana". International Journal of Business and Social Science, 5(8), 230238. 
Scott, William R. (2014) Financial Accounting Theory. Toronto : Pearson.

Shabibi, Al \& Ramesh. (2011) "An Empirical Study on the Determinants of Dividend Policy in the UK". International Research Journal of Finance and Economics, 80, 105-120.

Shahid, Muhammad Sadiq., Gul, Faid \& et al. (2016) "Ownership Structure, Board Size, Board Composition and Dividend Policy: New Evidence From Two Emerging Markets". Journal of Business StudiesJBS, 12.
Stulz, R.. (1990) "Managerial Discretion And Optimal Financing Policies". Journal of Financial Economics 26, 3-27.

Triwulan, Heni \& Wahidahwati. (2012) "Pengaruh Struktur Corporate Governance Dan Keputusan Keuangan Terhadap Kebijakan Deviden Dan Nilai Perusahaan". Jurnal Ilmu \& Riset Akuntansi, 1(12).

Yamin, S., Rachmach, L. A. \& Kurniawan, H. (2011) Regresi dan Korelasi Dalam Genggaman Anda. Jakarta: Salemba Empat. 